This item was submitted to Loughborough's Research Repository by the author.

Items in Figshare are protected by copyright, with all rights reserved, unless otherwise indicated.

\title{
The importance of family firm trusts in family firm governance
}

PLEASE CITE THE PUBLISHED VERSION

http://dx.doi.org/10.1111/etap.12124

\section{PUBLISHER}

John Wiley \& Sons, Inc. @ Baylor University

\section{VERSION}

AM (Accepted Manuscript)

\section{PUBLISHER STATEMENT}

This work is made available according to the conditions of the Creative Commons Attribution-NonCommercialNoDerivatives 4.0 International (CC BY-NC-ND 4.0) licence. Full details of this licence are available at: https://creativecommons.org/licenses/by-nc-nd/4.0/

\section{LICENCE}

CC BY-NC-ND 4.0

\section{REPOSITORY RECORD}

Scholes, Louise, and Nick Wilson. 2019. "The Importance of Family Firm Trusts in Family Firm Governance". figshare. https://hdl.handle.net/2134/19961. 


\title{
The Importance of Family Firm Trusts in Family Firm Governance
}

\author{
Louise Scholes \\ Durham University Business School \\ louise.scholes@durham.ac.uk \\ Nick Wilson \\ Leeds University Business School \\ nw@lubs.leeds.ac.uk
}

We explore the governance role of trusts in family firms and develop a typology which maps different configurations of boards and trustees with the longevity and efficiency of family firms. Suggestions are given for the proposed effects of these configurations and comparisons are made with Carney, Gedajlovic, and Strike’s (2014) 'Dead Money' discussion. Recognition is given to the fact that the dynamics of family firms is inextricably linked to the life cycle of families and that governance mechanisms need to react to changes and developments during the life-cycle if the family firm is to be conserved.

Acknowledgements: The authors would like to thank Mike Wright, Eric Gedajlovic, Michael Carney and Jim Chrisman for their helpful comments. We would also like to thank Helen Tavroges (Bond Dickinson LLP, Newcastle upon Tyne, UK) and Lucy Worwood (Browne Jacobson LLP, Nottingham, UK) for agreeing to be interviewed and for sharing their first-hand experience of family firm trusts. 


\section{Introduction}

Succession in family firms has been discussed at length in the literature and considers the processes and success factors for intergenerational succession (Chrisman et al, 2003; Miller et al., 2003; Molly et al., 2010). Carney, Gedajlovic, and Strike (2014) have considered something very novel with respect to succession, and that is the effect of inheritance law. They have explored the effects of inheritance laws and tax regimes in the different legislative areas of Germany, France, Hong Kong SAR, and the US on the (continuing) value of family firm assets and family firm longevity.

Carney et al. (2014) centre on 'dead money' as the focus of their argument. In the context of large corporates this refers to the firm hoarding surplus cash that is neither invested productively nor distributed to shareholders. The implication of the dead money argument is that family firms survive but are prone to stagnation as they cross generations within certain inheritance law regimes and legal codes. However, there is evidence that family firms do survive generations and continue to compete successfully; the existence of the 'Tercentarian Club', an association of firms that have remained in the family for at least 300 years, attest to the potential for longevity ${ }^{1}$. Carney et al. (2014) stimulate an interesting debate. Does the family business model have a longevity that is in contrast to the evanescence of other business models? Is 'dead money' an outcome of intergenerational succession and if so why and how significant is it? Is inherited wealth misallocated or merely redirected into equally valid investments?

Carney et al. (2014) suggest that property entails may have a particular negative effect on family firm intergenerational survival since they force the inheritor to pass on the undivided property to the next generation. It is quite possible to imagine a scenario where this

\footnotetext{
1 "The member companies have survived at least 47 recessions, a clutch of banking crises, stock market crashes, the start of the Industrial Revolution and the end of horsepower, two World Wars, the defeat of Napoleon and the rise of the internet" http://www.telegraph.co.uk/finance/yourbusiness/9772950/Theyre-300-years-old-and-still-in-business.html
} 
may not be beneficial for the firm or for the family if the beneficiaries are unable or unwilling to continue the business. This is an important concept to consider as the type of trust involved in the inheritance mechanism may have a bearing on the longevity of the family firm. Types of trust vary where at one end of the spectrum entails force a particular method of inheritance but at the other end trusts can be much more flexible. For example, in the UK, where entails no longer exist, trusts are governed by appointed trustees and are designed to manage the assets of the business in a way that benefits family members collectively. They provide a mechanism for a founding family shareholder to pass on her/his shares (wealth) to successive generations of the family according to specified wishes. The stability of ownership and governance structure gained by the use of trusts (collective ownership) is cited as an ingredient of successful succession planning amongst family businesses.

The following discussion relates to trusts in the UK, whose rules are based on common law, and considers two questions. First, how do trusts operate? Second, what effect could they have on the longevity and efficiency of a family business? These are important questions to consider since some trust structures may shorten the life of a family firm whereas some may help to preserve the business for successive generations. We recognize that laws vary across countries, especially with respect to civil versus common law.

\section{Family Firm Trusts}

The discussion is informed by interviews with legal practitioners in the UK actively involved in wealth management and family firm governance who have dealt frequently with succession issues. The interviewees are experts on setting up family trusts and are trustees of several family firms.

Trusts are established by the family business owner and allow assets (shares) to be transferred to the trustees. The trust is created as a 'benefits trust' such that income flows or capital gains from the company's assets are designated for the benefit of specified family 
members and/or employees. In the UK the main type of trusts are discretionary trusts (either set up during the lifetime of the business owner, a 'lifetime trust', or set up as part of a will, a 'will trust'). ${ }^{2}$ In these discretionary trusts a letter of wishes sketches out when, to what extent, and for what purpose a beneficiary may benefit from the trust fund, and generally accompanies a trust deed. A mission statement that presents a vision for the direction and management of the family firm often supports the owners' (settlors) letter of wishes. The mission statement builds in some flexibility for the trustees to adapt to changing family and business circumstances. The setting up of this type of trust was driven historically by the need to reduce inheritance tax. Although there are no longer strong tax incentives for setting up family trusts they are still a popular mechanism for managing family firm governance and succession. The trusts are established not only for estate planning and/or business succession but also to protect the shares in the event of family members divorcing, becoming bankrupt, wanting to take 'time out' of the business or even behaving irresponsibly. This is when the 'discretion' of trustees becomes important. Although their duty is to follow the letter of wishes or the will of the founder, if for some reason this is not possible, they have to use their discretion and make the right decision for the family, as beneficiaries.

The legal title to the shares is held by the trustees and whoever of the trustees is first named on the register of members is the person entitled to exercise any voting rights attached to the shares. However, as a matter of trust law, the trustees must always act unanimously, unless provided otherwise in the trust document. None of the beneficiaries has any voting rights. Trustees have unlimited liability should anything go wrong with the business and so becoming a trustee is not to be taken lightly. Trusts come to an end once the trust assets have

\footnotetext{
${ }^{2}$ There are two other types of trusts: (1) An interest in possession trust, which can be a lifetime trust or a will trust, but is more likely to be the latter. In this type of trust one or more people ("the life tenant(s)") are entitled to the income of the trust fund and there is often a power to make capital advances to them. The trust deed or will sets out what happens to the trust fund when the interest of the life tenant(s) comes to an end. (2) A contingent trust involves one or more people becoming entitled to the trust fund on reaching a specified age and provides what happens as to both capital and income prior to them reaching that age and what happens if they die before doing so.
} 
been distributed by the trustees to the beneficiaries. Each trust will have a long stop date by which distribution must be made called a perpetuity period - if the trust does not provide one then the general law will. Trusts created since 2009 can last for up to 150 years. Trustees generally have a wide discretion to sell the shares although it is possible to place restrictions against sale in the trust document or provide that a sale cannot take place without the consent of the "Protector" -- a named person who has a power of veto over various trust actions, such as the settlor who created the trust. Trustees can be sued by the beneficiaries if they keep the shares and they reduce significantly in value as it is their duty to increase the value of the trust fund. They cannot be sued, however, if there are restrictions placed on their powers of sale or powers of veto included in the trust document.

Trusts can relieve pressure associated with family business ownership. For example in instances where offspring are not capable, not able, or simply not interested in being actively involved in the family business and/or wish to gain other experience or qualifications before taking an active role in the business. These family members may well be relieved to have trustees who take on the responsibility for the ownership and governance of the business. One of our family firm lawyers gave us an example of this. The case was that of a small family business where the owner had three children: One child had disabilities and was unable to make decisions; another had a poor record in personal financial management and was estranged from the family; the third child had focussed on bringing up children and was not involved in the business. The business could therefore continue without active involvement of successors for a period of time with the trust acting as a temporary buffer and family members could re-join the business at a later stage.

Who are the trustees? Trustees can be family members, typically the founder of the business in the first instance, and/or trusted advisers and/or close family friends. The advisers can be individual lawyers, law firms, consultants or the company accountant. The Protector 
(often the founder) has to be consulted by the other trustees and may be granted the power to direct the trustees and also has the right to remove trustees. This protects against entrenchment of trustees and any actions deemed not to be in the best interest of the beneficiaries.

As significant or majority shareholders the trustees appoint the board of directors of the family company and have a duty to ensure that the assets of the business are managed in a way that provides maximum benefits to the family as beneficiaries. Trustees in some of the larger family firms can also be regarded as 'quasi directors' as they meet with directors regularly and therefore have significant influence.

\section{Family Business Longevity and Efficiency}

What effect can the trustees have on the longevity and efficiency of the business, the theme introduced by Carney et al. (2014)? What can give rise to conflicts that lead to the mismanagement and misallocation of family resources and assets or the accumulation of 'dead money'? Governance of a family business requires governance of the business and the family. Because of this complex 'family'-family business'-'family ownership’ system there is more scope for conflict, problems of maintaining cohesion, sustaining shared vision and prioritising the current needs of the family vis-à-vis the business and this is where a trust may have an important role. But does the trust help or hinder the family business? Does it smooth over or create conflict? Ideas drawn from agency theory may be illuminating. So-called multiple agency or double agent conflicts have been discussed in the context of the governance of firms (Allcock \& Filatotchev, 2010; Arthurs et al., 2008; Bruton et al. 2010; Child \& Rodrigues, 2003; Chrisman et al., 2012). An example can be found in initial public offerings (IPOs), where the owners and shareholders of the IPO firms are also the directors answerable to minority shareholders (Allcock \& Filatotchev, 2010). The IPO owners are thus both principal and agent, as would be the case if a non-family director of a family firm 
became a shareholding trustee or a trustee was appointed as a director. Any conflict of interest caused by the appointment of inappropriate trustees/directors could cause conflict and have a negative effect on value creation in the family firm. Further issues might arise if there are no longer any suitable family members that could play an active role in the business as directors, trustees or employees. Trustees are voting shareholders but also 'quasi' directors so on the one hand they have shareholder voting duties (but without the associated wealth of a shareholder) and this involves voting at shareholder meetings and electing suitable directors and on the other hand they are also directors themselves or at least 'quasi' directors with strong relationships with existing board members and influence over firm strategy. This puts trustees in a position where there could be a conflict of interest. As they don't actually own the shares in the company their role could be more akin to a traditional public company manager where the lack of equity ownership will alter their risk profile and may make them more risk averse and more interested in preserving the business and an income stream for beneficiaries rather than maximising firm value. The trustees' position is a complex and difficult one. On one hand they have to ensure an effective board is in place that monitors and directs the business and ensures long-term income flows for the family, and on the other hand they have to manage the family including satisfying the wishes of the business owner with respect to beneficiaries, providing incomes and capital for family members not involved in the business and using their discretion when family beneficiaries have different demands (e.g. not all offspring may want to sell the family business). Being voting shareholders (but without claim to the benefits of shareholding) and, at the same time 'directors', may compromise their effectiveness.

One way to understand the possible effects of the trustees on a family business might be to look at the composition of the trust and the board in terms of family versus non family membership. In this way we can estimate the influences of family and non-family members 
on the firm. We have constructed a matrix with Type of Board on the $\mathrm{Y}$ axis and Type of Trust on the $\mathrm{X}$ axis (Figure 1). We attempt to express the conjectured effects of the various combinations of trustees and board members (family, mixed or non family) in relation to the longevity and efficiency of the firm, and describe the outcome of these combinations primarily from the family perspective. We propose that the type of trust will influence the type of board and this will influence the longevity and efficiency of the firm, where longevity in this instance is the longevity of the firm as a family firm. We define a family firm as one which has family members on the board in addition to being majority owned by family.

\section{INSERT FIGURE 1. ABOUT HERE}

\section{Configuration A: Family Board, Family Trustees}

This configuration of board and trust is unlikely to exist in the UK as most trusts are initially set up as part of the will of the founder to ensure survival of the business and the safe transfer of ownership to the family through a trust. The trust will therefore consist of both family and non-family trustees. Even the less common discretionary lifetime trusts will comprise both family and non-family trustees in the first instance.

\section{Configuration B: Family Board, Mixed Trustees}

This could be the 'MOST LIKELY' configuration for smaller or second generation family firms. The trust will generally be composed of family and non-family, for example the next generation of family plus a trusted lawyer, accountant or family friend. This configuration can be expected to have positive effects on longevity and efficiency as nonfamily trustees will be able to provide advice to the board, select new board members and, at the same time, act in the interest of family beneficiaries. This configuration could prove problematic if the firm grows. The lack of additional skills on the board required for growth may become a limiting factor, may reduce efficiency, and may only be rectifiable if nonfamily employees with the required skills are appointed to the board. Non-family trustees can 
propose this and hire the right board members, or they can act as 'quasi' directors themselves. Otherwise the effect on the firm will be to potentially reduce longevity and efficiency. Configuration C: Family Board, Non-Family Trustees

In this configuration there are no family trustees. This situation is likely to arise if there are no suitable family members who can take up the position of trustee. The family members may not be capable or there could have been extreme family conflict. This is not a particularly advisable configuration since non family have sole (voting) control of the shares of the company and the appointment of the board. This non-family trust may be more susceptible to the double agency problem since there are no family members to balance the decision-making process. This configuration could lead to the end of the family firm. The 1970s pop star Marc Bolan and his advisers (trustees) opened many offshore accounts during his career in order to avoid paying UK income tax but when he died very little of his substantial wealth and continuing royalties was distributed to his family. Had he appointed a family trustee during his lifetime the outcome may have been different.

\section{Configuration D: Mixed Board, Family Trustees}

The disadvantage of having no non-family trustees is that additional advisory skills brought in from outsiders are absent which may mean that family trustees will be biased when advising the board and may only support family board members. This configuration would thus leave a family firm more open to the negative effects of altruism. This situation could arise if there is some conflict in a mixed trust leading to the non-family trustee stepping down, or if a non-family trustee retires, and may be a transient type. The longevity and efficiency of the firm may be negatively affected.

\section{Configuration E: Mixed Board, Mixed Trustees}

This is possibly the 'IDEAL' configuration for a family firm, an ideal board and ideal trustees with the right mix of skills and experience. In this configuration family members are 
on the board of directors and are trustee shareholders. The trustees can provide the right mix of family/non-family board members to create an 'ideal' board. The advantages of this configuration are present whether the firm is small or large, fast or slow growing, but will be most beneficial when the firm is in a fast moving industry, such as the high tech sector, when additional external skills are most needed and can be fully utilized. Longevity and efficiency of the family firm will be enhanced by this configuration.

\section{Configuration F: Mixed Board, Non-Family Trustees}

In this instance the lack of family trustees means that this firm is missing the influence of family owners, perhaps because of lack of capability or family conflict. The nonfamily trustees will have the ability to remove the family board members if they desire without opposition. It is a similar configuration to $\mathrm{C}$ above and could results in the birth of a non-family firm.

\section{Configuration G: Non-Family Board, Family Trustees}

This may be a transient configuration, created when a non-family trustee steps down and a new non-family trustee has not yet been appointed. It is an unlikely configuration because family trustees could and probably would prefer to appoint a family member to the board, providing of course there is a family member who is capable. Without a family member on the board this type of firm is not a family firm.

\section{Configuration H: Non-Family Board, Mixed Trustees}

A situation found possibly in large companies where at some stage the best candidate for the job of CEO is no longer the family founder/member. Warburtons Bakery was a recent UK example when, after five generations of family ownership, a non-family Managing Director took over. This type of firm is strictly no longer a family firm, since family governance is considered a necessary condition. However, family members still remain as trustees and voting shareholders. 


\section{Configuration I: Non-Family Board, Non-Family Trustees}

Family may be still involved in the business albeit at arms’ length but there may not be any family who are capable of running the company as director or as trustees. The family may still be shareholding beneficiaries but will have little influence on the business. There are no family members on the board so this type of firm is essentially a non-family firm. This is probably the final stage before a complete metamorphosis into a non-family firm, requiring family members to relinquish their rights as beneficiaries and sell their shares.

\section{Conclusion}

Family firm trusts in the UK are usually set up in the first instance by the founder who wants to protect the interest of both family and business, although they are mainly in the interest of the family in the first instance. We propose only two truly workable configurations of board and trust. The first is the IDEAL configuration where board and trust both contain a mixture of family and non-family members (Configuration E, Fig. 1). The second is a family board with a mixed trust. This may be suitable for smaller family firms or ones in slow moving, low tech. environments (Configuration B, Fig. 1) and is probably the MOST LIKELY configuration as most family firms are small. In both configurations longevity and efficiency are presumed to be maximized and double agency issues minimized.

The implications of UK-style trusts for the Carney et al. (2014) framework is that a more nuanced approach could be taken when looking at the impact of trusts, recognising that they are very heterogeneous. The entailed trusts discussed by Carney et al. (2014) force the distribution of undivided wealth (e.g. property) across family members and this may not be in best interests of the company or the family in the long run. This is not the case in the UK where trusts are more flexible, where trust and board configurations are interlinked and the trust has responsibility primarily to the beneficiaries but also to the firm. The configurations can enhance or diminish (like entails) the longevity and efficiency of the family firm and can 
also affect whether the firm continues to operate as a family firm. Figure 1 tends to imply a somewhat static environment but of course businesses and families change continuously. The board and its trustees can change over time as a business thrives or struggles, as individuals die or retire. The execution of the founders' original wishes can become more challenging over time, and a trust operating on behalf of many family members becomes more involved and complex. In addition, if the family breaks down in some way and leaves trustees running the company without effective family involvement a situation could arise where the nonfamily trustees may act in favour of the business and the firm may pass out of family hands.

Trusts deserve much greater research attention because of their incidence (most larger and second generation family firms in the UK have collective ownership through trusts), their strong governance role, and their potential impact on survival. Examining changes in longevity and efficiency of family firms before and after changes in trustees may provide insights into the real effects of trusts and would provide evidence about whether our conjectured effects are accurate. The role of trustees needs to be explored in more depth; are they simply shareholders who monitor the business at arms' length or are they 'quasi directors' who offer strategic advice, and what is their impact in both of these scenarios.

There are many questions that remain unanswered about the effects of family trusts and any answers will certainly add to, and enrich, the growing body of knowledge on governance in family firms and the factors affecting family firm survival. 


\section{References}

Allcock, D., \& Filatotchev, I. (2010). Executive Incentive Schemes in Initial Public Offerings: The Effects of Multiple-Agency Conflicts and Corporate Governance. Journal of Management, 36(3), 663-686.

Arthurs, J. D., Hoskisson, R. E., Busenitz, L. W., \& Johnson, R. A. (2008). Managerial Agents Watching other Agents: Multiple Agency Conflicts Regarding Underpricing in IPO Firms. Academy of Management Journal, 51(2), 277-294.

Bruton, G. D., Filatotchev, I., Chahine, S., \& Wright, M. (2010). Governance, Ownership structure and performance of IPO firms: The Impact of different types of private equity investors and institutional environments. Strategic Management Journal, 31(5), 491-509.

Carney, M., Gedajlovic, E., \& Strike, V. (2014). Dead Money: Inheritance Law and The Longevity of Family Firms. Entrepreneurship, Theory and Practice, 38, xxxx

Chrisman, J. J., Chua, J. H., \& Sharma, P. (2003). Current Trends and Future Directions in Family Business Management Studies: Toward A Theory of The Family Firm. Coleman White Series.

Chrisman, J. J., Chua, J. H., Steier, L. P., Wright, M., \& McKee, D. N. (2012). An agency theoretic analysis of value creation through management buy-outs of family firms. Journal of Family Business Strategy, 3(4), 197-206

Child, J., \& Rodrigues, S. B. (2003). Corporate Governance and New Organizational Forms : Issues of Double and Multiple Agency. Journal of Management and Governance, 7(4), 337360.

Miller, D., Steier, L., \& Le Breton-Miller, I. (2003). Lost in time: intergenerational succession, change, and failure in family business. Journal of Business Venturing, 18(4), 513-531.

Molly, V., Laveren, E., \& Deloof, M. (2010). Family Business Succession and Its Impact on Financial Structure and Performance. Family Business Review, 23(2), 131-147. 
Figure 1: Typology - Board vs. Trust Configurations of Family Firms

\begin{tabular}{|c|c|c|c|c|}
\hline \multirow{5}{*}{ 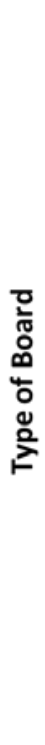 } & $\begin{array}{l}\text { Non } \\
\text { Family }\end{array}$ & $\begin{array}{l}\text { Configuration G } \\
\text { Not a family firm } \\
\text { Transient }\end{array}$ & $\begin{array}{l}\text { Configuration } \mathrm{H} \\
\text { Not a family firm }\end{array}$ & $\begin{array}{l}\text { Configuration I } \\
\text { Not a family firm }\end{array}$ \\
\hline & Mixed & $\begin{array}{l}\text { Configuration D } \\
\text { Transient }\end{array}$ & $\begin{array}{l}\text { Configuration E } \\
\text { IDEAL }\end{array}$ & Configuration $\mathrm{F}$ \\
\hline & Family & $\begin{array}{l}\text { Configuration A } \\
\text { Unlikely scenario }\end{array}$ & $\begin{array}{l}\text { Configuration B } \\
\text { MOST LIKELY }\end{array}$ & Configuration $\mathrm{C}$ \\
\hline & & Family & Mixed & Non Family \\
\hline & \multicolumn{4}{|c|}{ Type of Trust } \\
\hline
\end{tabular}

